\title{
PERFORMANCE OF WHEAT CULTIVARS TO IRRIGATION TREATMENTS AND DIFFERENT NITROGEN SOURCES UNDER CALCAREOUS SOIL.
}

\author{
E. Ghalab(1) M.M. Attia(2) and A.A. Sallam(2) \\ (1) Field Crop Res. Inst. A.R.C, Egypt. \\ (2) Soil, Water and Environment Res. Inst.; ARC, Egypt.
}

Received: Oct. 18,2017

Accepted: Dec. 6, 2017

\begin{abstract}
Two field experiments were conducted at Nubaria Agricultural Research Station in two successive seasons 2012-2013 and 2013-2014 to study the performance of wheat cultivars $\left(V_{1}=\right.$ Misr $_{1}$ and $\quad V_{2}=$ Sids12),four irrigation $\left(I_{1}=\right.$ irrigation water equals $50 \%$ of crop evapotranspiration $(E T C), I_{2}=$ irrigation water equals $75 \%$ of $(E T C) I_{3}=$ irrigation water equals $100 \%$ of $(E T C)$, and $I_{4}=$ irrigation water equals $125 \%$ of $(E T C)$ and nitrogen source $\left(N_{1}=\right.$ Ammonium nitrate and $N_{2}=$ Ammonia gas )on wheat biological, grain yields, yield components, water requirements and productivity of water.

Results showed that, biological and grain yields, plant height, number of spikes $/ \mathrm{m}^{2}$, number of kernels / spike and1000 kernels weight were significant affected by the interaction irrigation, nitrogen source and cultivar in both seasons. The highest values of biological and grain yields were 24.333 and 7.500 ton. ha $^{-1}$ in the first season respectively, while in the second season, values were 26.333 and 9.500 ton. ha ${ }^{-1}$, which obtained by irrigation with water equals to $100 \%$ of ETC, fertilization by gas ammonia with cultivarSids $12\left(I_{3} N_{2} V_{2}\right)$.

The total applied irrigation water for $I_{3}$ irrigation were 37.0 and $40.1 \mathrm{~cm}$ in both seasons, respectively. The highest values of productivity of irrigation water (PIW) were 2.00 and $2.62 \mathrm{~kg} \cdot \mathrm{m}^{3}$, in the first and second seasons, respectively.
\end{abstract}

Key words: Wheat - irrigation- cultivars - nitrogen source

\section{INTRODUCTION}

Wheat (Triticum aestivum, L.) is the most strategic cereal crop in the world as well as in Egypt. Many efforts are continuously paid for increasing wheat productivity to decrease the gap between production and consumption. This included vertical and or horizontal expansion. Increasing wheat production per unit area can be achieved by breeding, improvement and applying the optimum cultural practices including irrigation and fertilization. Within the arid and semi-arid regions, water shortage is a major limitation for crop production. Wheat crop needs sufficient available water and nitrogen to achieve optimum yields, quality and adequate grain-protein content.

In Egypt, wheat production does not meet the current demands. The Egyptian government is giving efforts to reduce the imported quantity to less than $50 \%$ of the total consumption (Abdrabbo et al., 2012). Crop yield, increase depends upon improving the efficiency of water use (Li et al., 2001). Over the last decades studies have been conducted on the regulation of watering and fertilization in arid and semi-arid regions. (De Juan et al., 1999 and Li et al., 2001). Wajid et al., (2002) reported that, wheat produced the highest grain yield by applying irrigation at definite growth stages. Crop water requirements are directly related to crop evapotranspiration (ETc) and vary depending on variety and growth stages. Evapotranspiration involves a highly complex set of processes, which are influenced by many factors related to climatic conditions. These conditions includes precipitation, meteorology factors and soil moisture. Aggarwal et al., (1986), showed that water 
use efficiency (WUE) for wheat decreased with increasing evapotranspiration (ET). Mossa and Abdel-Maksoud (2004) found that evapotranspiration (ET) value was increased as supplemental irrigation increased in wheat crop. Evapotranspiration ranged from 338 $382 \mathrm{~mm}$ at one third of full supplemental irrigation to 434 - $453 \mathrm{~mm}$ at full supplemental one.

Siam et al., (2012) showed that, plant height and dry weight per plant had a significant response to ammonia gas levels in combination with micronutrients. Siam et al., (2008) indicated that plant fresh and dry weights, weight of ear leaf, ear weight, 100grain weight, yield and yield components were significantly affected by the application of ammonia gas fertilizer, ammonium sulphate and urea in descending order. In general, the highest values of vegetative growth and yield components were obtained when the maize plants received ammonia gas fertilizer at the rate of $140 \mathrm{kgN} / \mathrm{fad}$. While, the lowest values were obtained from urea at the rate of $100 \mathrm{~kg} \mathrm{~N} / \mathrm{fad}$. Mirbahar et al., (2009) indicated that water stress significantly reduced height, spike length, spikelet per spike, grains per spike and 1000grain weight of all 25 wheat varieties. Abdelraouf et al., (2013) showed that, decreasing the irrigation requirements (IR) from $100 \%$ to $50 \%$, significantly decreased most of growth characters i. e; yield and yield attributes and protein, while, water use efficiency, significantly increased. However, decreasing IR from $100 \%$ to $50 \%$ decreased, grain, straw, and biological yield /fad from 1.91 to 1.27 , from 4.66 to 3.48 and 6.57 to 4.75 ton/fad, respectively. Akram et al., (2014), indicated that, water use efficiency increased with increasing rate of deficit irrigation regimes. Abdelkhalak et al., (2015) showed that, the irrigation treatment gave the lowest values for water consumptive use, grain, straw, biological yield and 1000-grain weight. Nitrogen fertilizer as gas ammonia up

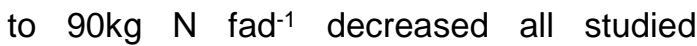

characters, except, yield which has insignificant difference between nitrogen levels. Significant differences were detected among the three wheat varieties in all studied characters during both seasons. Misr1 cultivar was superior and gave the highest value of all studied characters and yield response to water factor (Ky) followed by Misr2.While, water productivity (WP) decreased with increasing irrigation events and nitrogen levels and reached the maximum values at three irrigation treatments and at $90 \mathrm{Kg} \mathrm{N}^{-1}$. So, irrigating during growing season and applying $75 \mathrm{Kg} \mathrm{N}$ $\mathrm{fad}^{-1}$ in the form of gas ammonia gave the highest values of yield and yield components of Misr1 wheat cultivar under North Delta conditions. Zaki et al., (2016) indicated that, different sources of nitrogen fertilizer had significant effect on all characters of yield and yield components in two seasons, except, for number of spikes /plant. In addition, interaction between wheat cultivars and nitrogen sources was detected for growth characters except for leaf area /plant at 110 days after sowing. While, plant height, number of tillers /plant, grain yield/plant, grain yield/fad, straw yield/fad, biological yield /fad were significantly affected by the interaction between wheat cultivar and nitrogen source.

The objectives of this work were to study the effects of wheat cultivars, irrigation treatments and nitrogen source on biological, grain yield, yield components, water requirements and productivity of water.

\section{MATERIALS AND METHODS}

Two field experiments were carried out during the winter seasons of 2012 -2013 and 2013 2014 at the experimental farm of Nubaria Agricultural Research Station. Soil samples were taken before sowing to determine soil physical, and chemical properties (Page et al., 1982), and some soil hydro-physical parameters. Results of analysis were presented in Tables 1 and 2. 
Table 1: chemical properties of soil samples.

\begin{tabular}{|c|c|c|c|c|c|c|c|c|c|c|c|c|}
\hline \multirow{2}{*}{$\begin{array}{c}\text { Soil } \\
\text { depth } \\
(\mathrm{Cm})\end{array}$} & \multirow{2}{*}{$\begin{array}{l}\text { Total } \\
\text { N\% }\end{array}$} & \multicolumn{2}{|c|}{$\begin{array}{c}\text { Available } \\
\text { U g/g }\end{array}$} & \multicolumn{4}{|c|}{$\begin{array}{l}\text { Soluble cations } \\
\qquad \text { Meq/l }\end{array}$} & \multicolumn{3}{|c|}{$\begin{array}{c}\text { Soluble anions, } \\
\text { Meq/l }\end{array}$} & \multirow{2}{*}{$\mathrm{pH}$} & \multirow{2}{*}{$\begin{array}{l}\text { EC } \\
\mathrm{ds} / \mathrm{m}\end{array}$} \\
\hline & & $\mathrm{K}$ & $P$ & $\mathrm{~K}+$ & $\mathrm{Na}+$ & $\mathrm{Mg}++$ & $\mathrm{Ca}++$ & $\mathrm{Cl}-$ & $\begin{array}{c}\text { So4- } \\
-\end{array}$ & $\mathrm{HCO}-$ & & \\
\hline $0-30$ & 0.09 & 131 & 2.1 & 1.20 & 6.11 & 1.68 & 7.81 & 9.80 & 2.77 & 4.23 & 8.4 & 1.68 \\
\hline $30-60$ & 0.03 & 107 & 1.7 & 1.11 & 5.71 & 2.67 & 8.71 & 9.44 & 3.44 & 5.32 & 8.3 & 1.82 \\
\hline
\end{tabular}

Table 2: Field capacity, wilting point, available soil moisture and bulk density at the experimental site.

\begin{tabular}{|c|c|c|c|c|}
\hline $\begin{array}{c}\text { Soil Depth } \\
(\mathrm{cm} .)\end{array}$ & $\begin{array}{c}\text { Field capacity } \\
(\%)\end{array}$ & $\begin{array}{c}\text { Wilting point } \\
(\%)\end{array}$ & $\begin{array}{c}\text { Available water } \\
(\%)\end{array}$ & $\begin{array}{c}\text { Bulk density } \\
(\mathrm{g} . \mathrm{cm}-3)\end{array}$ \\
\hline $0-15$ & 26.7 & 14.8 & 11.9 & 1.11 \\
\hline $15-30$ & 24.4 & 12.6 & 11.8 & 1.17 \\
\hline $30-45$ & 23.8 & 11.9 & 11.9 & 1.19 \\
\hline $45-50$ & 20.7 & 11.3 & 9.4 & 1.22 \\
\hline Average & 23.9 & 12.7 & 11.25 & 1.17 \\
\hline
\end{tabular}

The studied treatments included two cultivars, four irrigation treatments and two different nitrogen sources. The experimental design was a split-split-plot involving main treatments (irrigation), sub main treatments (nitrogen sources) and sub-sub main (wheat cultivars) with three replicates. Irrigation treatments were;

$I_{1}=$ Irrigation water equals to $50 \%$ of crop evapotranspiration (ETC) based on class A Pan.

$\mathrm{I}_{2}=$ Irrigation water equals to $75 \%$ of ETC.

$I_{3}=$ Irrigation water equals to $100 \%$ of ETC.

$\mathrm{I}_{4}=$ Irrigation water equals to $125 \%$ of ETC.

The different nitrogen sources were:

$\mathrm{N}_{1}=$ Ammonium nitrate at the of $100 \mathrm{~kg} \mathrm{~N} \mathrm{fad}^{-1}$

$\mathrm{N}_{2}=$ Gaseous ammonia $82 \%$, at the rate of $100 \mathrm{Kg} \mathrm{N} \mathrm{fad}^{-1}$.

Wheat cultivars were: Misr1 and Sids12.
Plot area was $42 \mathrm{~m}^{2}$, treated with $30 \mathrm{Kg}$ $\mathrm{P}_{2} \mathrm{O}_{5} /$ fad. (as calcium super phosphate $15 \%$ ), $48 \mathrm{~kg} \mathrm{~K}_{2} \mathrm{O} / \mathrm{fad}$ (as potassium sulphate $48 \%$ ). Wheat grains of Misr1 and Sids12 cultivars were sown on November $25^{\text {th }}$ and December $5^{\text {th }}$, whereas, harvested by $10^{\text {th }}$ and $12^{\text {th }}$, May, in the first and second seasons, respectively. Data were obtained from the center of each plot $\left(30 \mathrm{~m}^{2}\right)$ to avoid border effects.

Agronomic traits were determined:

1- Plant height $(\mathrm{cm})$ was measured from the soil surface to the tip of the main spike at maturity, excluding owns.

2- Number of spikes per $m^{2}$ was recorded as the number of spike per $\mathrm{m} 2$.

3- Number of kernels per spike was determined as the average of number for kernels per ten spikes taken random from each plot.

4- Thousand kernel weight was calculated as the weight of a 1000-grain sample. 


\section{E. Ghalab, et al.,}

5- Grain yield was determined as the weight of grain harvested for the inner rows per unit area and converted to grain ton per hectare.

6- Biological yield was determined as total weight of all above ground dry matter of each plot and converted to biological ton per hectare.

Irrigation water was controlled and measured by using water flow meter connected to an irrigation pump placed very close to the experimental plots to ensure high water application efficiency. The total amounts of the precipitation were 134.2 and $78.2 \mathrm{~mm}$ in the first and second seasons, respectively, (Table 3).

The potential evapotranspiration (ETp) in $\mathrm{mm} /$ day values, that were calculated according to Class A pan evaporation method (F.A.O, 1979), were used to calculate the amounts of applied irrigation water as follows:

$$
\begin{gathered}
E T c=E T p \times K c, \\
E T p=E \text { pan } \times K \text { pan }
\end{gathered}
$$

Where:

ETc = Crop evapotranspiration in $\mathrm{mm} /$ day

ETp = Potential evapotranspiration in $\mathrm{mm} /$ day,

$\mathrm{Kc}=$ Crop coefficient (for wheat crop as reported by (F.A.O.1984),
$\mathrm{E}$ pan = Pan evaporation daily values in $\mathrm{mm}$ /day (Meteorological station in Nubaria research station),

$\mathrm{K}$ pan = Pan coefficient, $\mathrm{K}$ pan values depend on the relative

Humidity, wind speed and site condition (bare or cultivated) $\mathrm{K}$ pan value of 0.75 was used for the experimental site .

Daily water requirements (WR) in $\mathrm{mm} /$ day were calculated as follows:

Where:

$$
W R=\frac{E T c}{E a(1-L R)}
$$

Ea= Application efficiency \% (70 \%for control surface irrigation system)

$\mathrm{LR}=$ Leaching requirements (20\%of WR in Calcareous soils)

Productivity of irrigation water (PTW) was calculated according to the following equation (Ali e. al., 2007)

Where:

$$
P I W=\frac{G Y}{I W}
$$

$\mathrm{PIW}=$ Productivity of irrigation water $(\mathrm{Kg}$ grain $\mathrm{m}^{-3}$ )

$\mathrm{GY}=$ Grain yield $\left(\mathrm{Kg} \mathrm{fad}^{-1}\right)$

IW $=$ Water applied $\left(\mathrm{m}^{3}{ }^{3} \mathrm{ad}^{-1}\right)$

Data were statistically analyzed according to Steel and Torrie (1980) for all studied traits using SAS Program (2007).

Table 3: Precipitation in mm during $2012 / 2013$ and 2013/2014 growing seasons.

\begin{tabular}{|c|c|c|}
\hline seasons & 2012-2013 & 2013-2014 \\
\hline Month & Precipitation in $\mathrm{mm}$ & Precipitation in $\mathrm{mm}$ \\
\hline Nov & 8.2 & 7.8 \\
Dec & 42.0 & 19.5 \\
Jan & 61.2 & 19.8 \\
Feb & 13.1 & 13.2 \\
Mar & 3.0 & 11.1 \\
Apr & 3.6 & 6.8 \\
May & 3.1 & 0.0 \\
\hline Total & 134.2 & 78.2 \\
\hline
\end{tabular}




\section{RESULTS AND DISCUSSIONS \\ 1- Biological and grain yields :}

Results of biological and grain yields for the two growing seasons were presented in Tables 4,5 and 6 . Table 4 showed that, biological and grain yields were significantly affected by the irrigation treatments in the two growing seasons. $l_{3}$ irrigation treatment produced the highest values of biological and grain yields in the two growing seasons (22.708 and 24.708 ton.ha ${ }^{-1}$ for the $1^{\text {st }}$ and $2^{\text {nd }}$ seasons, respectively). While the other studied three treatment produced less biological yield. Biological yield of treatment recorded significant increases of $(25.8,13.5$ and $3.8 \%$ ) and $(23.2,12.3$ and $3.4 \%)$ in the first and second seasons, respectively relative to $I_{1}, I_{2}$ and $I_{4}$ irrigation treatments, respectively. Also, grain yield of $I_{3}$ treatment, surpassed that the other three treatments (7.104 and 9.104 ton.ha $^{-1}$ in the two successive seasons, respectively). The grain yield increases reaches $(36.1,16.1$ and $3.7 \%)$ and $(26.1,12.1$ and $2.9 \%)$ in the first and second seasons compared to $I_{1}, I_{2}$ and $I_{4}$ irrigation treatments, respectively. Also, results indicated that, biological and grain yields were significantly affected by different nitrogen source in both growing seasons. $\mathrm{N}_{2}$ treatment (ammonia gas) produced higher value of biological (21.166 and 23.166 ton.ha${ }^{1}$ that represented increases of 5.0 and $4.6 \%$, over the other source in the first and second seasons, respectively. In addition, grain yield increases under ammonia gas treatment $\left(\mathrm{N}_{2}\right)$ reached 6.47 and 8.47 ton. ha ${ }^{-1}$ in the first and second seasons, respectively. Biological and grain yield were significantly differed between the two cultivars in the two growing seasons. Biological yield of Sids12 was 21.141 and 23.141 ton. ha ${ }^{-1}$ in the first and second seasons, respectively. Increases over Miser1 cultivar reached 4.8 and $4.4 \%$ for in the first and second seasons, respectively. Grain yield of Sids12showed significant increases of 6.0 and $4.5 \%$ in the two seasons, respectively, over Misr1.

Table 5 showed the effect of interactions between irrigation treatment and nitrogen sources (IXN), irrigation and cultivars (IXV) and nitrogen sources and cultivars (NxV) on biological and grain yields. Data indicated that, irrigation water equals to $100 \%$ of ETc and application of ammonia gas $\left(\mathrm{I}_{3} \mathrm{~N}_{2}\right)$, gave the highest values of biological and grain yields. While, the least significant values were obtained with irrigation water equals $50 \%$ of ETC and ammonium nitrate $\left(I_{1} N_{1}\right)$. Also, irrigation water equals $100 \%$ of ETC and Sids12 Cultivar $\left(I_{3} \bigvee_{2}\right)$ gave the highest values of biological and grain yields. While the least significant values were obtained from irrigation water equals $50 \%$ of ETc with Misr1 cultivars $\left(\mathrm{I}_{1} \mathrm{~V}_{1}\right)$.

Table 6 showed that biological and grain yields were significantly affected by the interaction among irrigation, nitrogen source and cultivars (IXNXV), in both study seasons. Irrigation water equals $100 \%$ of ETC, application of ammonia with Sids12 cultivar $\left(I_{3} N_{2} V_{2}\right)$ gave the highest values of biological and grain yields in the two growing seasons. The obtained results were in agreement with those reported by Abdelraouf et al., (2013) AbdElkhalek et al., (2015) and Zaki et al., (2016). Abdel Aziz et al., (2010) found that, anhydrous ammonia was more effective in increasing straw yield over ammonium nitrate. Ammonia gas easily combines with organic matter in soils and resist leaching and loss, therefore, it is readily utilized by crop all over the growing season resulting in higher values of biological and grain yields.

\section{2- Yield components :}

The differences in yield components, number of spikes $/ \mathrm{m}^{2}$, number of kernels Ispike, and 1000-kernels weight (g), in 2012/2013 and 2013/2014 were listed in Table 4,5 and 6. Table 4 showed that, all characters of yield components were significantly affected by irrigation treatments in both seasons. Irrigation treatments $I_{3}$ and $\mathrm{I}_{4}$ gave the highest values of all characters. Also, number of spikes $/ \mathrm{m}^{2}$ in both seasons, and no of kernels /spike in the second season are only significantly affected by nitrogen source. 


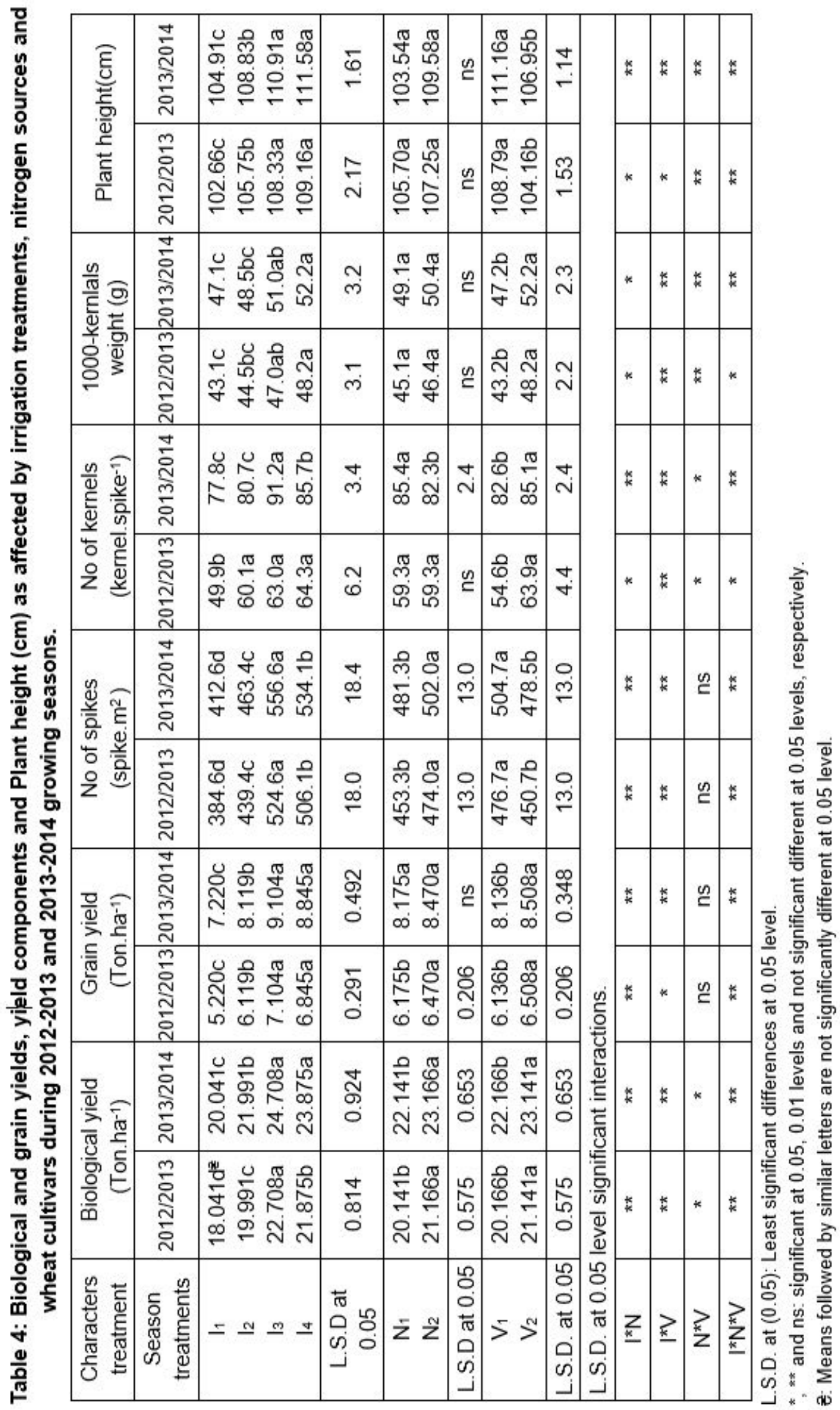


Performance of wheat cultivars to irrigation treatments and different.

\begin{tabular}{|c|c|c|c|c|c|c|c|}
\hline 蒿 & 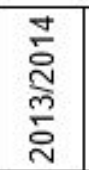 & 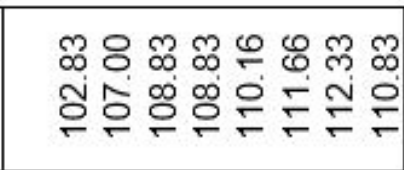 & 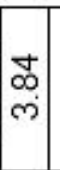 & 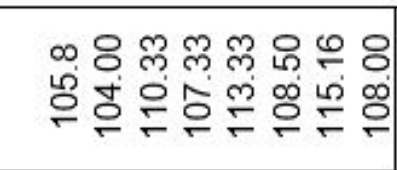 & $\mid$ & $\begin{array}{l}000 \\
0\end{array}$ & ๙ั \\
\hline 竞 & $\begin{array}{l}\text { m. } \\
\stackrel{\circ}{N} \\
\stackrel{\sim}{\circ} \\
\end{array}$ & 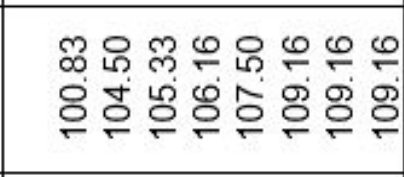 & $\begin{array}{l}\mp \\
\dot{q}\end{array}$ & 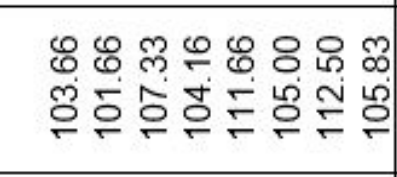 & ले & $\begin{array}{llll}\overline{0} & 0 & 0 & 0 \\
0 & 0 \\
\circ & 0 & 0 & 0 \\
\circ & 0 & 0\end{array}$ & 농 \\
\hline 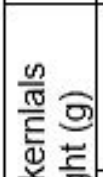 & 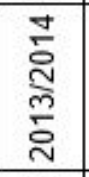 & 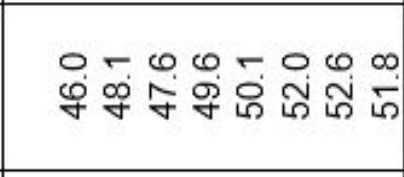 & min & 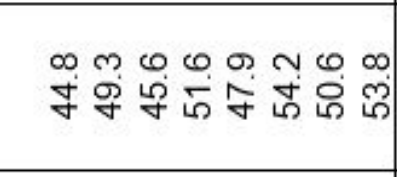 & $\ddot{q}$ & 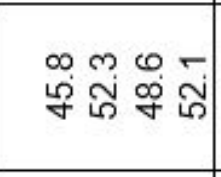 & $m$ \\
\hline 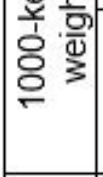 & 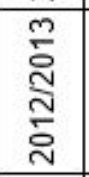 & 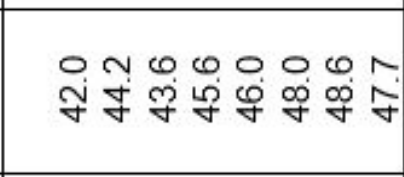 & $\begin{array}{c}\sim \\
\text { in }\end{array}$ & 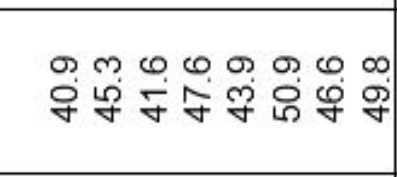 & $\stackrel{\sim}{\forall}$ & 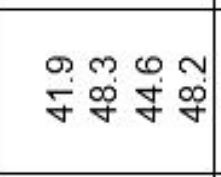 & ๗ֶ \\
\hline 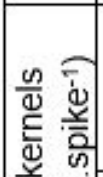 & 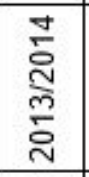 & 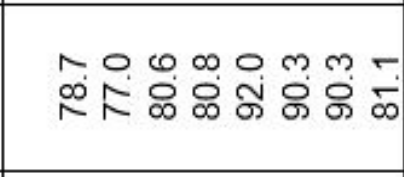 & $\stackrel{\infty}{+}$ & 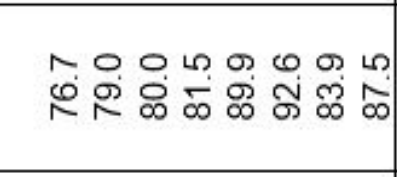 & $\begin{array}{l}8 \\
\text { in }\end{array}$ & $\begin{array}{lrcc}0 & \bar{\tau} & 0 & 0 \\
\infty & \infty & \infty & \infty\end{array}$ & $\begin{array}{l}0 \\
0\end{array}$ \\
\hline 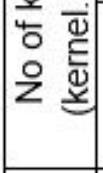 & $\underset{\stackrel{m}{\check{N}}}{\stackrel{m}{\check{N}}}$ & 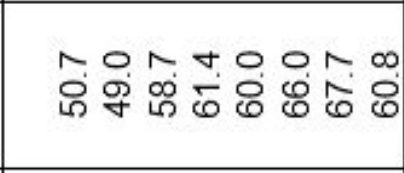 & $\stackrel{\oplus}{\circ}$ & 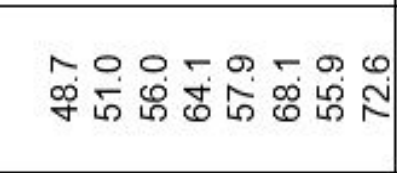 & $\mid$ & 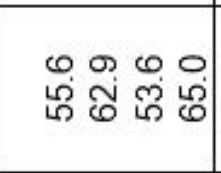 & $\stackrel{\infty}{\sim}$ \\
\hline 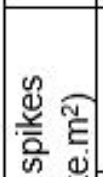 & 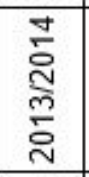 & 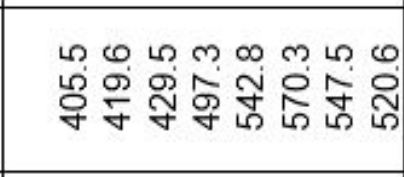 & $\begin{array}{l}N \\
\text { ले } \\
\end{array}$ & 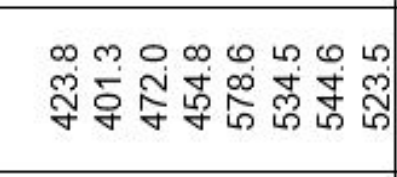 & 일 & 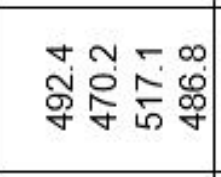 & $\stackrel{\leftrightarrow}{\check{c}}$ \\
\hline 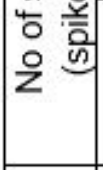 & 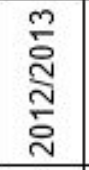 & 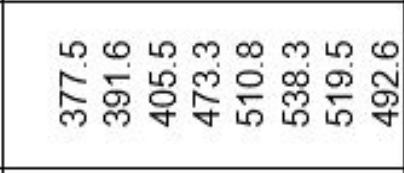 & ஸे & 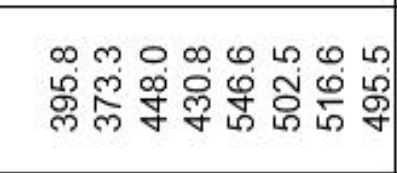 & 일 & 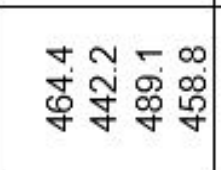 & $\stackrel{\text { on }}{\check{C}}$ \\
\hline$\frac{0}{20}$ & 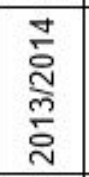 & 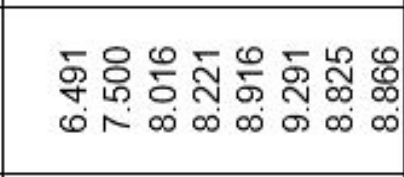 & $\mid \begin{array}{c}\tilde{T} \\
6 \\
0 \\
0\end{array}$ & 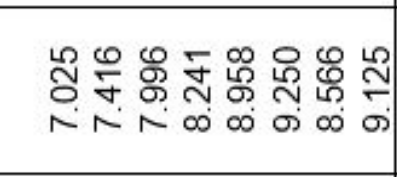 & 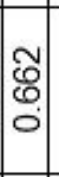 & 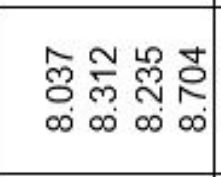 & $\stackrel{\leftrightarrow}{\check{d}}$ \\
\hline 次 든 & 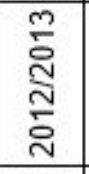 & 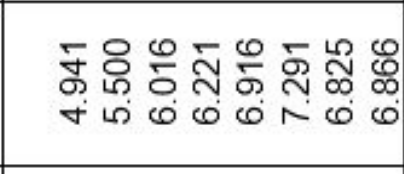 & $\mid$ & 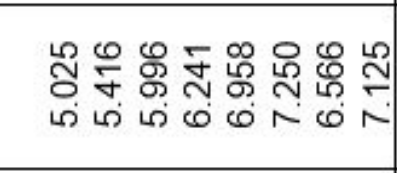 & $\mid \begin{array}{c}\hat{m} \\
\stackrel{9}{0} \\
0\end{array}$ & 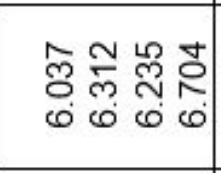 & $\stackrel{\text { in }}{\check{~}}$ \\
\hline 竞 & 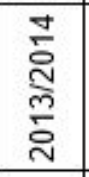 & 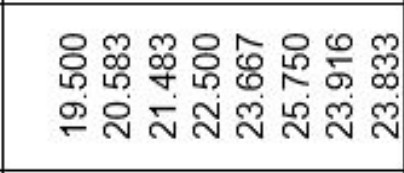 & ্ָলু & 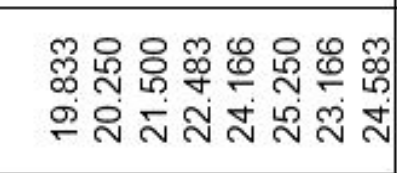 & $\underset{\sim}{\stackrel{N}{-}}$ & 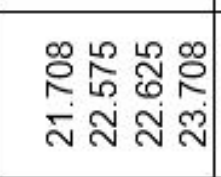 & $\stackrel{\Sigma}{E}$ \\
\hline 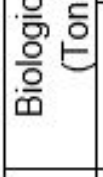 & $\frac{\mathfrak{m}}{\stackrel{\sim}{\tilde{N}}}$ & 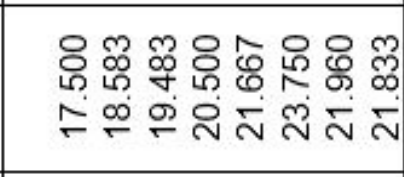 & $\underset{N}{\sim}$ & 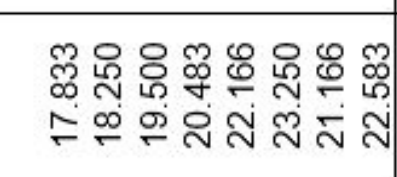 & $\stackrel{\sim}{m}$ & 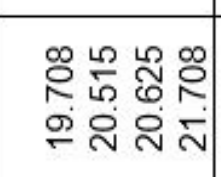 & $\stackrel{\widetilde{N}}{\stackrel{-}{-}}$ \\
\hline 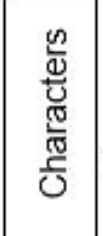 & 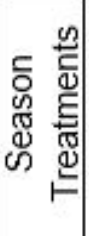 & 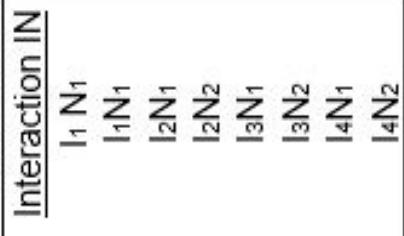 & 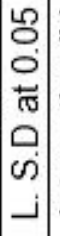 & 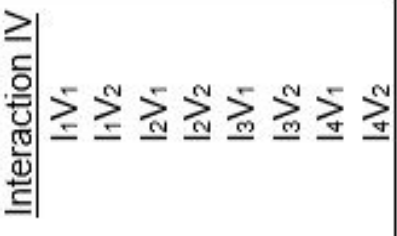 & 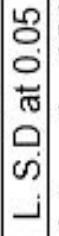 & 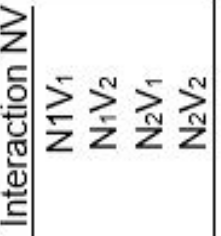 & 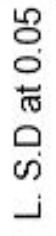 \\
\hline
\end{tabular}


E. Ghálab, et al.,

\begin{tabular}{|c|c|c|c|}
\hline \multirow{2}{*}{ 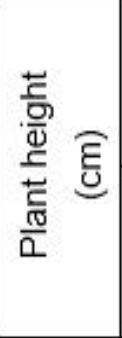 } & 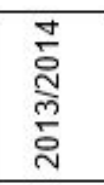 & 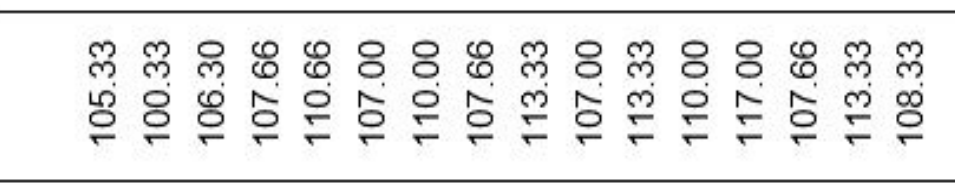 & $\underset{m}{m}$ \\
\hline & 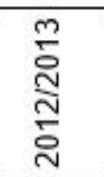 & 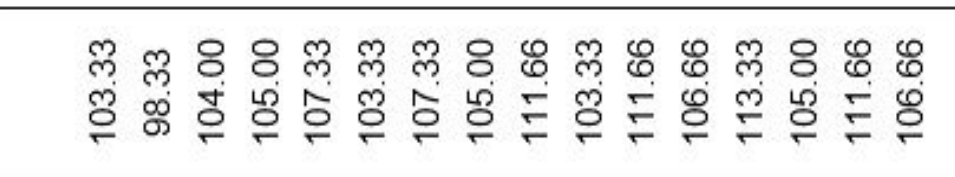 & $\stackrel{\text { mे }}{\forall}$ \\
\hline \multirow{2}{*}{ 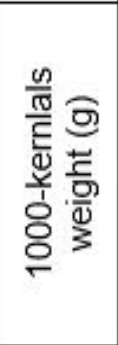 } & 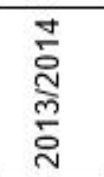 & 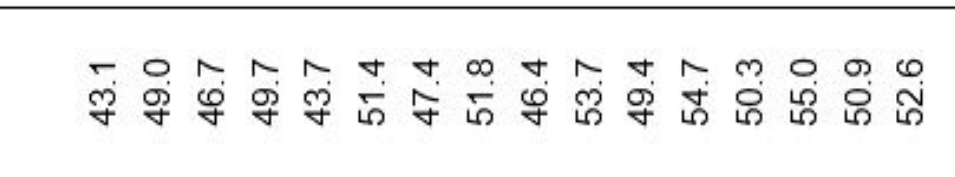 & $\stackrel{+}{\circ}$ \\
\hline & 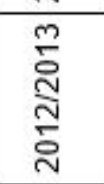 & 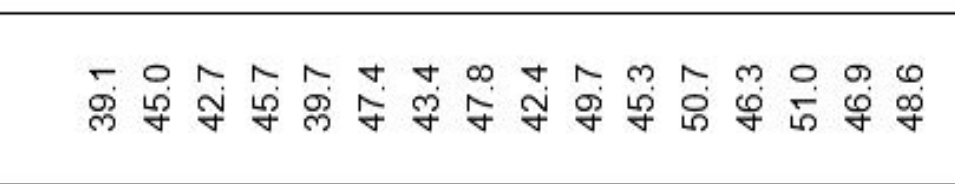 & $\underset{\omega}{\sim}$ \\
\hline \multirow{2}{*}{ 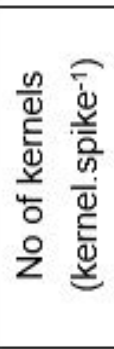 } & 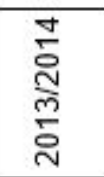 & 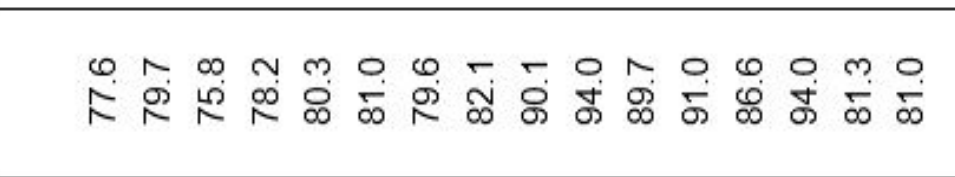 & $\begin{array}{l}\infty \\
\omega^{\circ}\end{array}$ \\
\hline & 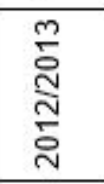 & 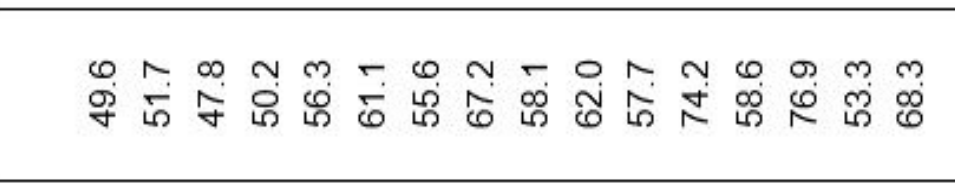 & $\stackrel{+}{\stackrel{\leftarrow}{\leftarrow}}$ \\
\hline \multirow{2}{*}{ 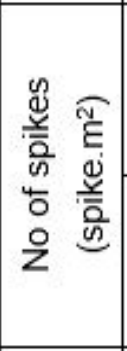 } & 啇 & 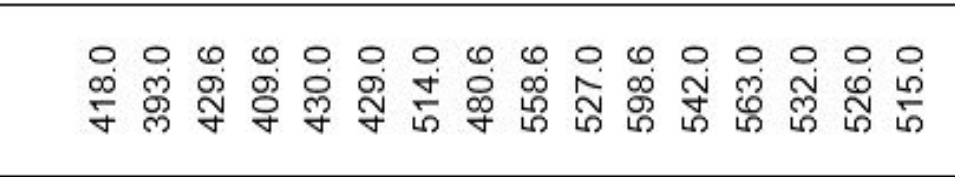 & $\begin{array}{l}\infty \\
\dot{\infty}\end{array}$ \\
\hline & 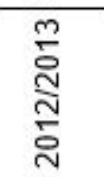 & 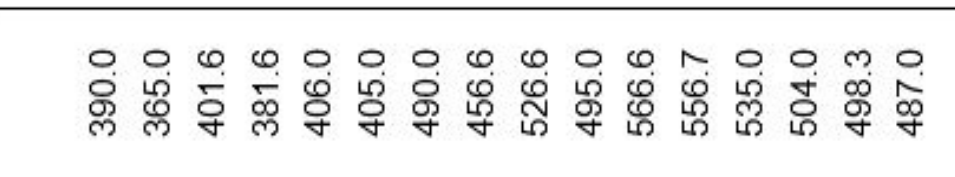 & $\stackrel{\infty}{\mathbb{\rho}^{\infty}}$ \\
\hline \multirow{2}{*}{ 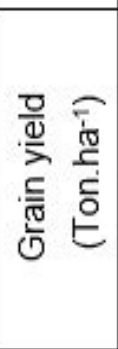 } & 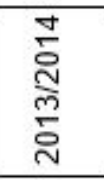 & 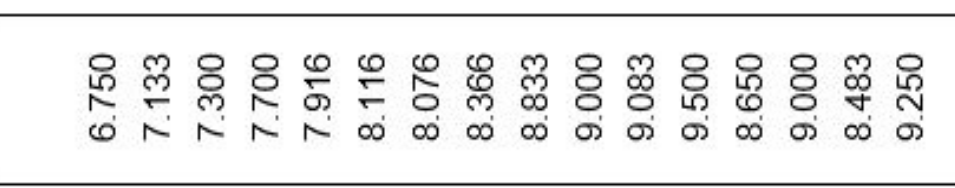 & $\begin{array}{l}\text { J } \\
\text { O } \\
\text { ó }\end{array}$ \\
\hline & 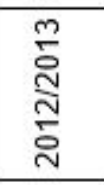 & 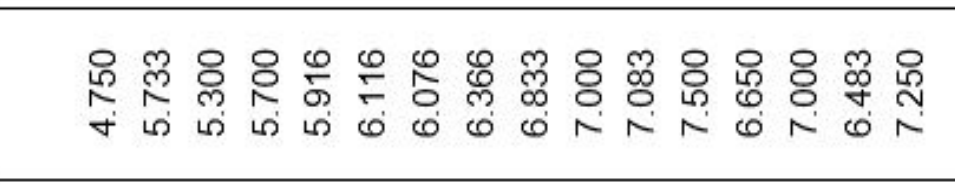 & 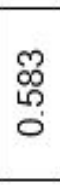 \\
\hline \multirow{2}{*}{ 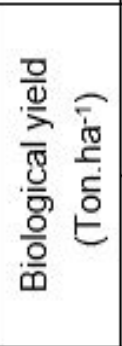 } & 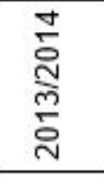 & 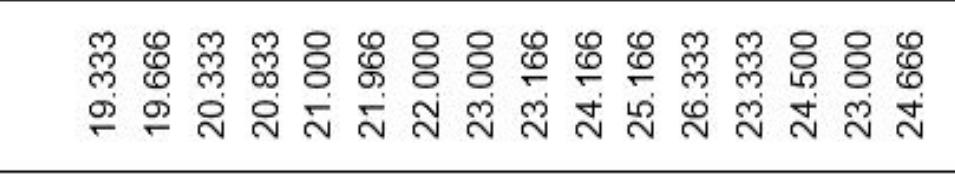 & $\stackrel{\substack{+\infty}}{-}$ \\
\hline & 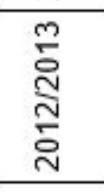 & 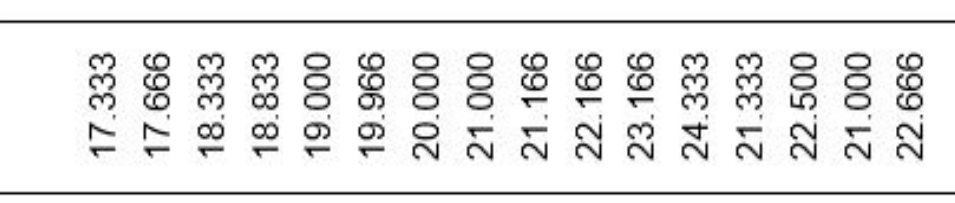 & 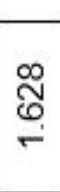 \\
\hline 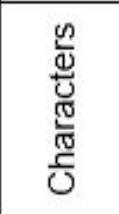 & 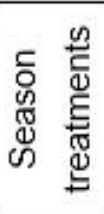 & 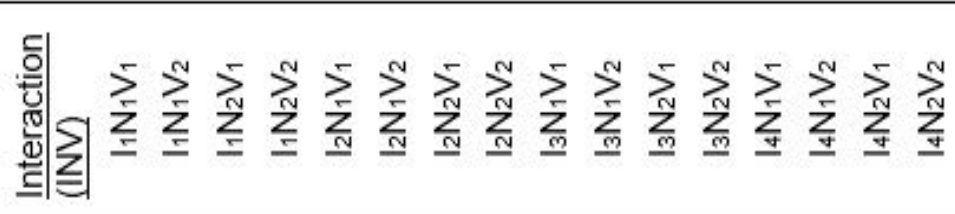 & 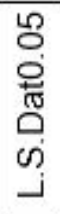 \\
\hline
\end{tabular}


Number of spikes $/ \mathrm{m}^{2}$ is the main yield component contributes to grain yield production. Results in Table 6 show that, the number of spikes. $\mathrm{m}^{2}$ in the two seasons were detected for the two studied cultivars under irrigation treatment $\mathrm{l}_{3} \quad(100 \% \quad \mathrm{ETc})$ and ammonia gas fertilization. There results might indicate that, using the whole dose of ammonia gas before planting increased availability of nitrogen in early and late tillering stages which increased number of spikes $/ \mathrm{m}^{2}$ in the two cultivars which was reflected in higher grain yield under $I_{3} \mathrm{~N}_{2}$ treatments.

Abdel Aziz and Mazen (2010) stated that, anhydrous ammonia reacts with water and increase nitrogen availability in soil. Therefore, wheat growth, tillering, spike development and grain filling might be efficient leading to high grain yield.

Data of number of kernels/spike were presented in Tables 4, 5 and 6. Data revealed that number of kernels/spike of Sids12 wheat cultivar $\left(V_{2}\right)$ is higher than that of Misr1 $\left(V_{1}\right)$ under all treatments indicating genetic variability between these two cultivars. The highest number of kernels/spike was detected in the two cultivars under $I_{3} \mathrm{~N}_{2}$ treatments (Table 6). Irrigation with 100\% ETc and fertilization with ammonia gas resulted in higher number in kernels/spike for the two cultivars over other irrigation and fertilizer treatments. The treatment $I_{3} \mathrm{~N}_{2} \mathrm{~V}_{2}$ produced the highest number of kernels. Number of kernels per spike is an important yield component which is determined at spike initiation stage. Availability of nitrogen and water at this stage increase number of spikelet which results in an increase in number of kernels/spike. $\mathrm{I}_{3}$ and $\mathrm{N}_{2}$ increased the availability of nitrogen and water in that growth stage which indicated the superiority of ammonia over the second source of ammonia in wheat production.

Wheat grain weight is determined at the grain filling stage following anthesis and fertilization. Grain weight is highly affected by the translocation of assimilates from leaves and stems to grains. $l_{3}$ and $l_{4}$ produced the highest grain weight, which reflects the importance of the availability of water in grain filling period. Nitrogen fertilization with ammonia gas produced heavier kernels under $I_{3}$ irrigation treatment confirming previous results.

Table 5 showed the interaction between irrigation and nitrogen source $(I \times N)$, irrigation and wheat cultivars $(I \times V)$ and nitrogen source and cultivar $(\mathrm{N} \times \mathrm{V})$. Results indicated significant effect of the interaction (I $x \mathrm{~N})$ and $(\mathrm{I} \times \mathrm{V})$. Results showed a significant effect of the interaction between $\mathrm{N} \times \mathrm{V}$ on all characters of yield components except for number of spikes $/ \mathrm{m}^{2}$ in both seasons. Table 6 showed that, no of spikes $/ \mathrm{m}^{2}$, number of Kernels/spikes, 1000-kernelsweight and plant height were significantly affected by the interaction between irrigation, nitrogen source and wheat cultivars $(I \times N \times V)$, in both seasons.

Results of yield components clarify the superiority of the treatment $I_{3} \quad N_{2} \quad V_{2}$ in biological and grain yield.

Although plant height is mainly controlled by genetic make-up it was highly affected by environmental conditions. The highest values of plant height were detected under the two irrigation treatments $I_{3}$ and $I_{4}$. Misr 1 cultivar was taller than Sids12. Higher values of plant height contribute to biological yield. The obtained results are agreement with those reported by Siam et al., (2008), Siam et al., (2012) and Mir bahar et al., (2009).

\section{4- Water requirements and productivity of irrigation water (PIW) :}

The month and seasonally amount of irrigation water (water requirements) to the wheat crop according to the irrigation treatments during the two growing seasons are listed in Table 7. The highest monthly value of applied irrigation water occurred during March in both seasons for the all irrigation treatments. The total amount of water requirement for the 50, 75, 100 and 
$125 \%$ of ETc irrigation treatments were 28.4 , $33.0,37.0$ and $42.7 \mathrm{~cm}$ in the $1^{\text {nd }}$ season and $29.4,34.6,40.1$ and $44.4 \mathrm{~cm}$ in the $2^{\text {th }}$ season respectively. The obtained results are agreement with the results of Li et al (2001), Wajid et al., (2002), and Moussa and abdelMaksoud (2004).

Table 8 showed that, the maximum values of irrigation water productivity (PIW) were obtained when irrigation water equals $50 \%$ of ETc, with application of ammonia gas and with cultivation Sids12 wheat cultivar $\left(\mathrm{I}_{1} \mathrm{~N}_{2}\right.$ $V_{2}$ ) in both seasons. The maximum values of
PIW were 2.00 and $2.62 \mathrm{~kg}$ wheat grain yield per $\mathrm{m}^{3}$ water applied in the first and second seasons, respectively. PIW decreased with increasing the mounts of irrigation water, and reached the minimum value when wheat plants were irrigated with of water equals $125 \%$ of ETc, with application of ammonia gas, and with cultivation of Misr-1 cultivar ( $\mathrm{I}_{4}$ $\mathrm{N}_{2} \mathrm{~V}_{1}$ ) in both seasons. These results are agreement with the results of Aggarwal et al., (1986), Li et al., (2001), Akram et al., (2014) and Zaki et al., (2016).

Table 7: Monthly and total (water requirements in $\mathrm{cm}$ as affected wheat by irrigation treatments during 2012-2013 and 2013 -2014 growing seasons.

\begin{tabular}{|c|c|c|c|c|c|c|c|c|c|}
\hline Season & Treat & Nov. & Dec. & Jan & Feb & Mar & Apr & May & Total \\
\hline 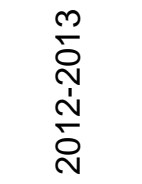 & $\begin{array}{l}11 \\
12 \\
13 \\
14\end{array}$ & $\begin{array}{l}1.2 \\
1.2 \\
1.2 \\
1.2\end{array}$ & $\begin{array}{l}7.1 \\
7.1 \\
7.1 \\
7.1\end{array}$ & $\begin{array}{l}5.9 \\
5.9 \\
5.9 \\
5.9\end{array}$ & $\begin{array}{l}4.1 \\
4.3 \\
4.5 \\
4.7\end{array}$ & $\begin{array}{c}4.4 \\
6.8 \\
8.4 \\
11.1\end{array}$ & $\begin{array}{l}4.1 \\
5.3 \\
6.8 \\
8.7\end{array}$ & $\begin{array}{l}1.6 \\
2.4 \\
3.1 \\
4.0\end{array}$ & $\begin{array}{l}28.4 \\
33.0 \\
37.0 \\
42.7\end{array}$ \\
\hline 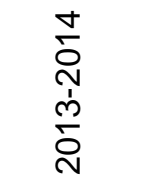 & $\begin{array}{l}11 \\
12 \\
13 \\
14\end{array}$ & $\begin{array}{l}- \\
- \\
-\end{array}$ & $\begin{array}{l}9.5 \\
9.5 \\
9.5 \\
9.5\end{array}$ & $\begin{array}{l}5.8 \\
5.8 \\
5.8 \\
5.8\end{array}$ & $\begin{array}{l}3.6 \\
4.5 \\
4.9 \\
5.1\end{array}$ & $\begin{array}{c}4.6 \\
6.3 \\
8.6 \\
10.2\end{array}$ & $\begin{array}{l}3.7 \\
5.6 \\
7.2 \\
9.2\end{array}$ & $\begin{array}{l}2.2 \\
2.9 \\
4.1 \\
4.6\end{array}$ & $\begin{array}{l}29.4 \\
34.6 \\
40.1 \\
44.4\end{array}$ \\
\hline
\end{tabular}

Table 8 : Productivity of irrigation water (PIW) for grain yield $\left(\mathrm{kg} \cdot \mathrm{m}^{3}\right)$ during 2012-2013 and 2013-2014 growing seasons.

\begin{tabular}{|l|c|c|}
\hline \multirow{2}{*}{ treatments } & \multicolumn{2}{|c|}{ Productivity of irrigation water (PIW) } \\
\cline { 2 - 3 } & $2012-2013$ & $2013-2014$ \\
\hline${ }_{1} \mathrm{~N}_{1} \mathrm{~V}_{1}$ & 1.67 & 2.30 \\
${ }_{1} \mathrm{~N}_{1} \mathrm{~V}_{2}$ & 1.80 & 2.43 \\
${ }_{{ }_{1}} \mathrm{~N}_{2} \mathrm{~V}_{1}$ & 1.87 & 2.48 \\
${ }_{1} \mathrm{~N}_{2} \mathrm{~V}_{2}$ & 2.00 & 2.62 \\
\hline${ }_{2} \mathrm{~N}_{1} \mathrm{~V}_{1}$ & 1.79 & 2.29 \\
${ }_{{ }_{2}} \mathrm{~N}_{1} \mathrm{~V}_{2}$ & 1.85 & 2.35 \\
${ }_{{ }_{2}} \mathrm{~N}_{2} \mathrm{~V}_{1}$ & 1.84 & 2.33 \\
${ }_{{ }_{2}} \mathrm{~N}_{2} \mathrm{~V}_{2}$ & 1.93 & 2.42 \\
\hline${ }_{3} \mathrm{~N}_{1} \mathrm{~V}_{1}$ & 1.85 & 2.20 \\
${ }_{{ }_{3}} \mathrm{~N}_{1} \mathrm{~V}_{2}$ & 1.89 & 2.24 \\
${ }_{{ }_{3}} \mathrm{~N}_{2} \mathrm{~V}_{1}$ & 1.91 & 2.27 \\
${ }_{{ }_{3}} \mathrm{~N}_{2} \mathrm{~V}_{2}$ & 2.00 & 2.39 \\
\hline${ }_{4} \mathrm{~N}_{1} \mathrm{~V}_{1}$ & 1.56 & 2.16 \\
${ }_{{ }_{4}} \mathrm{~N}_{1} \mathrm{~V}_{2}$ & 1.64 & 2.24 \\
${ }_{{ }_{4}} \mathrm{~N}_{2} \mathrm{~V}_{1}$ & 1.52 & 2.12 \\
${ }_{{ }_{4} \mathrm{~N}_{2} \mathrm{~V}_{2}}$ & 1.70 & 2.31 \\
\hline
\end{tabular}




\section{CONCLUSIONS}

From the obtained results it could be concluded that:

1- Maximum biological and grain yields were obtained by irrigation with amount of water equals $100 \%$ of ETc, application of ammonia gas and cultivation sids-12 wheat cultivar.

2- There was significant effect due to the interaction between irrigation treatments, nitrogen sources and wheat cultivars on plant height and yield and yield components (no. of spikes $/ \mathrm{m}^{2}$, no of Kernel /spike, 1000-kernel weight).

3- Seasonal range of irrigation requirements for wheat crop was 37.0 to $40.1 \mathrm{~cm}$.

4- The heights value of the productivity of irrigation water for wheat crop was obtained by irrigation with amount of water equals $50 \%$ of ETc, with application of ammonia gas and with cultivation Sids-12 wheat cultivar.

\section{REFERENCES}

AbdelAziz, I. M., O. A. O. Mazen, H. A. Awadalla and Nadia M. Hemeid (2010). Wheat production as affected by anhydrous ammonia, organic compost and biofertitizer application. Egypt. J. Appl. Sci., 25 (8B): 598-613.

Abdelkhalak, A.A., R.KH. Darwesh and M.A.M. El- Mansoury (2015). Response of some wheat varieties to irrigation and nitrogen fertilization using ammonia gas in North Nile Delta region. Annals of Agricultural Science 60 (2), 245-256.

Abdelraouf, R.E., S. F. El-Habbasha, M. H., Taha and K. M. Refaie (2013). Effect of irrigation water requirement and fustigation levels on growth, yield, and water use efficiency in wheat. Middle East Journal of Scientific Research, 16 (4) : 441 -450 .

Abdelrabbo, M.A.A., M.K. Hassanein and A.A.A. Farag (2012). Water regime and nitrogen from for different wheat cultivars under sprinkler irrigation system. J.Boil. chem. Environ Sci. 3, 229 - 252.
Aggarwal, P.K., A. K. singh, G. S., chaturvedei and S.K., Singh (1986). Performance of wheat and triticale cultivars in a variable soil- water environment. 11. Evapotranspiration water use efficiency, harvest index and grain yield. Field crop Res. 13,301-315.

Akarm, M., R.M. Iqbal and M. Jamil (2014). The response of Wheat to integrating effects of drought stress and nitrogen Management. Bulgarian Journal of Agricultural science, 20(2): 275-286.

Ali, M.H., M. R. Hoque, A. A.Hassan and A. KHair (2007). Effect of deficit irrigation on yield, water productivity and Economic returns of wheat. Agric. Water Manage 92 (3),151-161.

De Juan, J.A., J. M. Tarjuelo, J. F. Ortega, M. Valiente and P. Crrion (1999). Management of water consumption inagriculture - amodel for economic optimization of water use: application to a sub - humid area. Agric. Water Mange. 40, 303-313.

Dunn, S. M. and R. Makey (1995). Spatial variation in evapotranspirationand the influence of land use on catchment hydrology. J. Hydrol. 171, 49-73.

F.A.O. (1979). Yield response to water by Doorenbos, J. and A. Kassam. FAO. Irrigation and Drainage paper No.33 Rome, Italy.

F.A.O. (1984). Crop water requirement, by Doorenbos, J. and W.O. Pruitt. Irrigation and Drainage paper No 24. Rome, Italy.

Li, F. M., Q.H. Song, H. S. liu, F. R. Li and X. L. liu (2001). Effect of pre-sowing irrigation and phosphorus application on water use and yield of spring wheat under semi- arid Conditions. Agric. Water Manage. 49,173183.

Mirbahar, A.A., G.S. Markhand, A.R. Mahar, S.A. Abro and N.A. Kanhar (2009). Effect of water stress on yield and yield components of wheat varieties. Pak. J. Bot., 41 (3):1303-1310. 
Moussa, A.M. and H.H. Abdel- Maksoud (2004). Effect of soil moisture regime on yield and its components and water use efficiency for some wheat cultivars. Ann. Agric. Sci. Ain Shams Univ. Egypt, 49: 515-530.

Page, A. L., L. R. H. Miller and D.R Keeny (1982). Methods of Soil Analysis. Am. Soc. Inc., Madison, WI, USA.

SAS (2007). Guide for Personal Computers. Version 9 ed. SAS end. SAS institute, Cary. N.C, U.S.A.

Siam, H. S., M G. Abd EL-Kader and H. L. EL-Alia (2008). Yield and yield components of maize as affected by different sources and application rates of nitrogen fertilizer. Res. J. of Agric. And Biol. Sci, 4(5): 399-412.

Siam, H. S., M. G. Abd EL-Kader and M.S. Abd EL-Fattah (2012). Effect of ammonia gas and some micronutrients on maize plants .1-plant growth and mineral uptake. Australian J. of Basic and applied Sciences, 6(3): 462-473.

Steel, R. G. and J.H. Torrie (1980). Principles and Procedures of Statistics. $2^{\text {nd }}$ Edi, New york, McGrew Hill Book company - 196 P.

Wajid, A. A. Hussain, M. Maqsood, A. Ahmed and M. Awais (2002). Influence of sowing date and irrigation levels on growth and grain yield of wheat. Pak. J. Agric. Sci. 39,22-24.

Zaki, N. M., M.S. Hassanein, A. G. Ahmed, M. A. Ahmed and M. M. Tawifk (2016). Response of two wheat cultivars to different nitrogen sources in Newly cultivated land .Res. J. of pharm Biolog. and chem. Scie. 7 (6): 410-416. 
سلولك اصناف القمح لمعاملات الري ومصادر مختلفه من النيتروجين

\section{تحت الأراضي الجيريـه}

الحسينى غلاب جلال(1) ، محمود محمد عطية(2) ، أحمد عبد الهادي سلام(1)

(1) قسم بحوث القصح - معهد بحوث المحاصيل الحقلية - مركز البحوث الزراعية

(2) قسم بحوث المقننات المائية والري الحقلي - معهد بحوث الااراضي والمياه والبيئة - مركز البحوث الزئية الزراعية المخلص العربي

نفذت تجربة حقلية في موسمي 2012-2013 و 2013 -2014 بححطة بحوث النوبارية لدراسة سلوك صنفين من القمح لمعاملات ري ومصدرين مختلفين من التسميد النيتروجيني. صمدت التجربة في قطع منشقة مرتين، القطع الرئيسية هى معاملات الري والقطع الشقيه الاولى مصدرين مختلفين من التسميد النيتروجيني والقطع المنشقه الثانيه صنفين من القدح. كانت معاملات

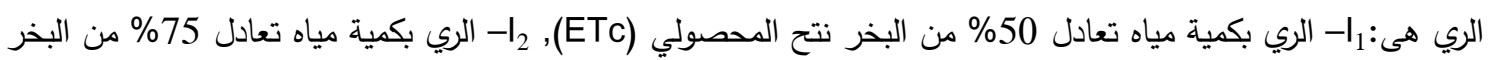

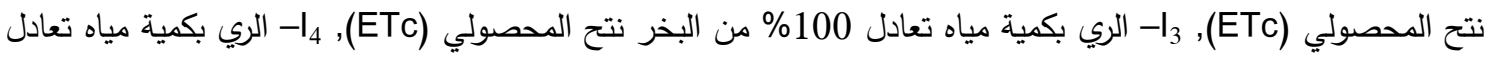

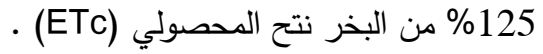

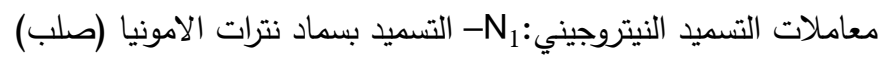

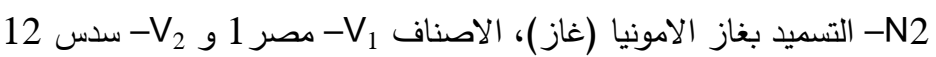

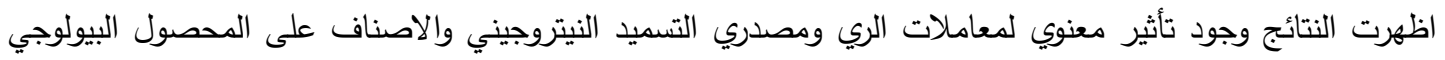

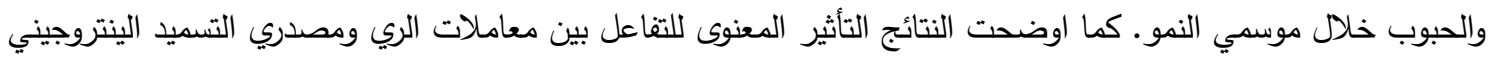
والاصناف على الدحصول البيولوجي والحبوب وطول النبات علاوة على مكونات المحصول (عدد السنابل / متر مربع وعدد

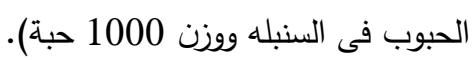

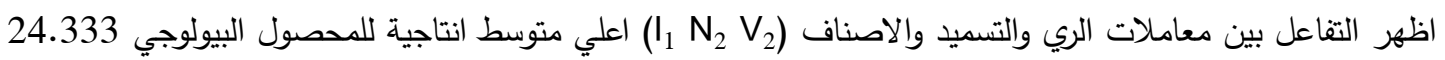

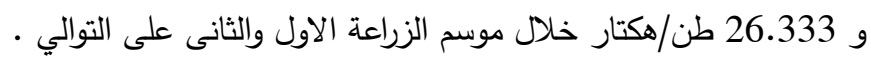

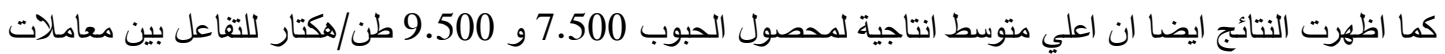
الري والتسميد والاصناف

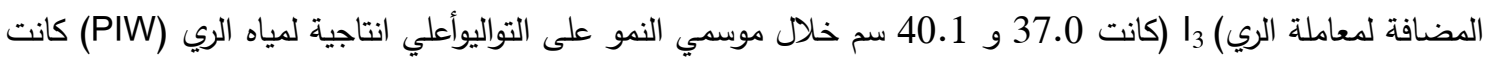
لمعاملة الري) ا ( 2.00 و 2.62 كجم لكل متر مكعب مياه مضاف خلال موسمي النمو على التوالي .

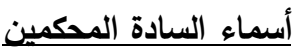
كلية الزراعة - جامعة الأسكندرية

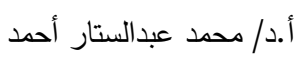
أ.د/ شعبان أحمد الثمارقة كلية الزراعة - جامعة المنوفية 
E. Ghalab, et al., 